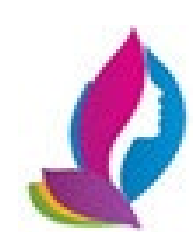

Contents List available at RAZI Publishing

Malaysian Journal of Geosciences

Journal Homepage: http://www.razipublishing.com/journals/malaysian-journal-of-geosciences-mig/

https://doi.org/10.26480/mjg.01.2017.38.42

\title{
SLOPE STABILITY STUDY AROUND KAMPUNG KUALA ABAI, KOTA BELUD, SABAH, MALAYSIA
}

\section{Ismail Abd Rahim \& Mohd Noor Raffee Usli}

Natural Disasters Research Centre, Faculty of Science and Natural Resources,Universiti Malaysia Sabah, Jalan UMS,88400 Kota Kinabalu, Sabah, Malaysia,Phone: +6 088320000 (5743)

This is an open access article distributed under the Creative Commons Attribution License, which permits unrestricted use, distribution, and reproduction in any medium, provided the original work is properly cited.

\section{ARTICLE DETAILS}

Article history:

Received 22 January 2017

Accepted 03 February 2017

Available online 05 February 2017

Keywords:

Kota Belud, Crocker forma-tion, factor of safety (FOS), kinematic analysis,

kinetic analysis, slope design

\begin{abstract}
The study area is located in the northwestern part of Kota Belud, Sabah and underlain by Late Eocene-late Early Miocene of the Crocker formation. The objectives of this study are to determine the mode of failures, factors of safety and to propose slope designs. Engineering geological mapping, kinematic analysis, new approach of adjustment factor, dry density analysis, stereographic measurement, kinetic analysis and prescriptive measures were used to produce geological map and described rock mass characteristics, to determine the mode of failure and optimum slope angle, the most critical mode of failure, unit weight of the rock, wedge angle, factor of safety and slope protection and stabilization measures, respectively. Results of this study shows that the mode of failures are wedge failure, the factors of safety ranges from 1.93 to 4.43 which generally considered stable and the proposed slope design are flattening the slope angle between $310-450$, installation of the wire mesh, rock trap ditch and spot rock bolting.
\end{abstract}

\section{INTRODUCTION}

Slope failure is a main issue in lives and property loss all around the world. Modification or creating of artificial slope by improper slope cutting and design are sometimes contributed to the formation of slope failures. In order to design a stable slope, engineering geological mapping and stability analysis are vital to be conducted.

Rock mass classification system is one of a design tool in determining early design for the slopes. Another universal slope stability analysis used for slope designs are stereographic and kinematic method, kinetic (limit equilibrium analysis), numerical methods [continuum modeling (e.g. finite element, finite difference) and discontinuum modeling (e.g. distinct element, discrete element)], hybrid/coupled modeling, rockfall simulation and probabilistic approach.
Occurrences of the more than a cubic meter (m3) falling rock block at the bottom of rock cut slope in Kampung Kuala Abai road have become an issue for this study. These rock blocks are large enough in damaging engineering structures or properties, causing injury and even death. Structure and road impended by even small spills of rock material are in addition an inconvenience for the public's and motorists (Maerz, 2000).

The study area is underlain by Crocker Formation of Late Eocene - late Early Miocene ages which have been experienced complex tectonic history and unique geological structures (Figure 1). This formation is a turbidite deposits that consists of interbedded sandstone, siltstone and shale units. The Bouma sequence can be identified in some beds and sandstone to shale ratios vary between outcrop.

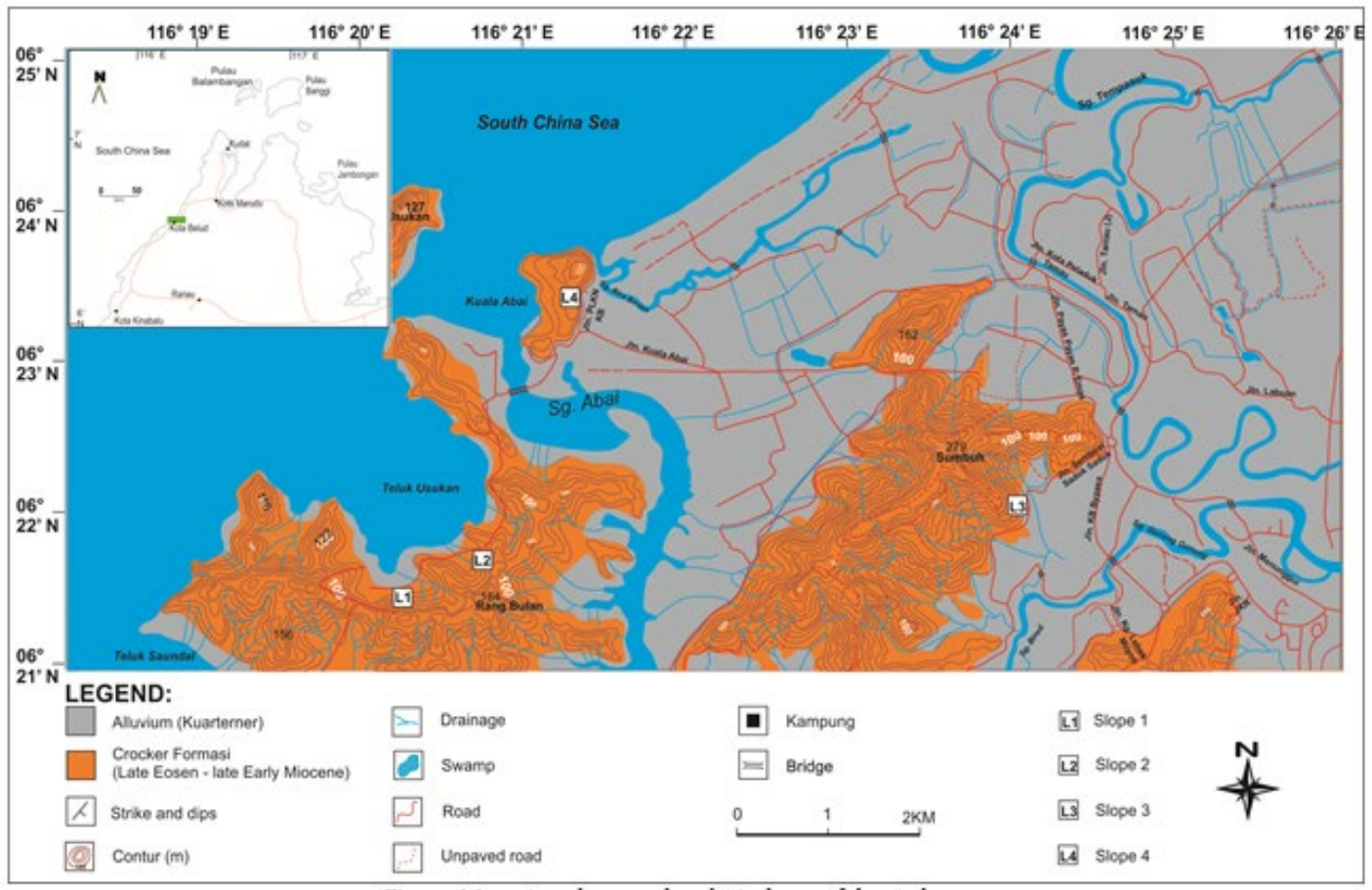

Figure 1 Location, slopes and geological map of the study area. 
The sandstone is grey to brown, moderately well sorted, very fine to medium grained lithic wacke. It is very thin to thick-bedded. The beds of fine sandstone and very fine sandstone are rich in sole marks, load cast, flute cast, graded bedding, parallel, cross and convolute lamination and trace fossil. The siltstone is grey to greenish grey, predominantly of silt material, hard when fresh but soft and buff when weathered in thin bedded (less than $5 \mathrm{~cm}$ ).

Shale unit can be divided into grey and red shales. The grey shale unit has represented by rhythmic interbedded of thick grey shale and thin very fine sandstone, parallel to wavy laminated, less well developed sole marks, occasional trace fossil (Nereites association) and common slumps deposition. The red shale is interbeds with very thin siltstone, parallel to wavy laminated, occasional slumps deposit and patched of grey or green shales.

The objectives of this study are to determine the mode of failures, factors of safety and to propose slope designs.

\section{METHODOLOGY}

Engineering geological mapping, kinematic analysis, new approach of adjustment factor, dry density analysis, stereographic measurement, kinetic analysis and prescriptive measures have been used in this study. Engineering geological mapping includes lithological, slope and slope failure mapping and random discontinuity survey (ISRM, 1981).

Markland test (Markland, 1972) has been used in kinematic analysis to determine the mode of failure and optimum slope angle. The most potential mode of failure for more than one failure in a slope has been determined by the new approach of adjustment factor, NAAF method (Ismail Abd Rahim, et al., 2012). Dry density analysis (ISRM, 2007) has been conducted to determine unit weight of the rock. The wedge angle i.e. the angle between wedge plane, sliding plane, slope face or upper slope face, line of intersection for wedge geometry and normal plane in wedge model have been measured by stereographic method.

Factor of safety (F.O.S.) has been determined by kinetic analysis (Kliche, 1999). In conducting the kinetic analysis, the model of the wedge is assumed without tension crack and water pressure. The steps in calculating F.O.S. are as follows;

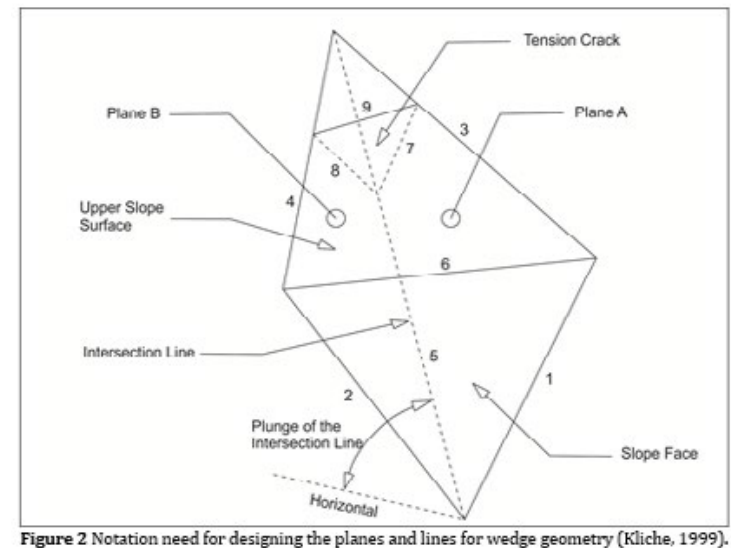

dentification of the planes forming the wedge and their number end lines in stereonet (Figure 3 ).

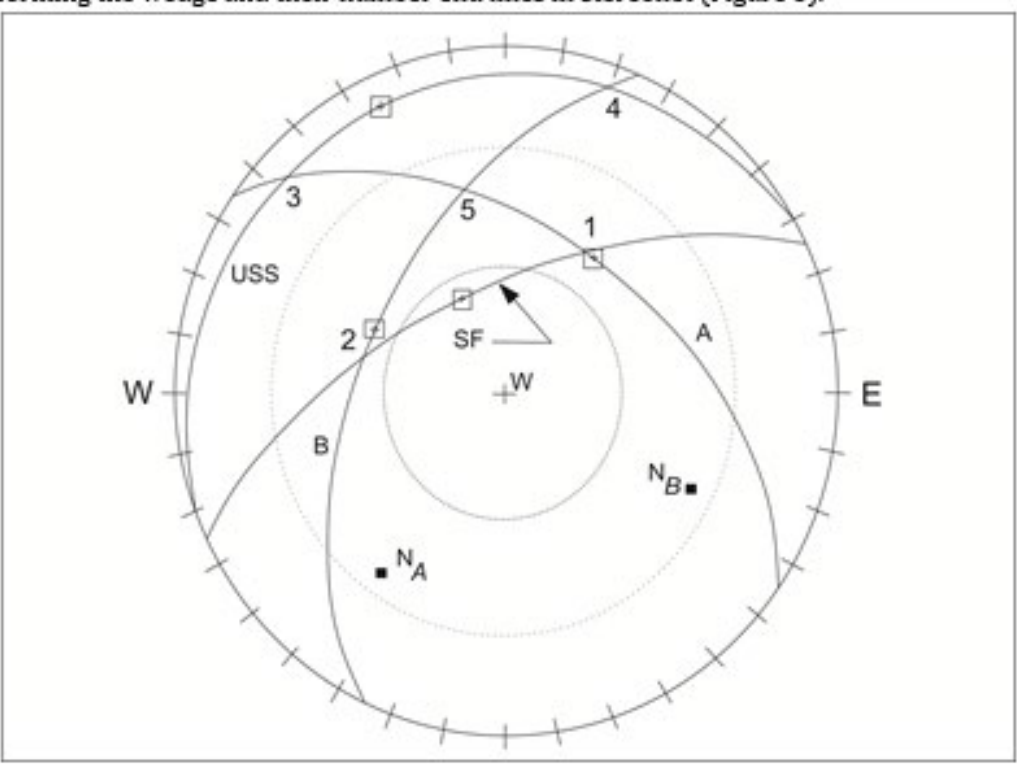

Figure 3 Notation of planes forming the wedge and the numbering of wedge end lines (Kliche, 1999). 
Figure 5 Location on the stereonet of wedge weight, W; the normal Ni, NA and NB and angle to the normal, $\beta \mathrm{i}(\delta \mathrm{i}), \delta \mathrm{A}$ and $\delta \mathrm{B}$ (Kliche, 1999).

The resisting force on plane A and B according to Mohr-Coulomb criterion are as follows;

$\mathrm{CA}+\mathrm{NAtan} \mathrm{A}$

$\mathrm{CB}+\mathrm{NB} \tan \mathrm{B}$

The driving force parallel to the line of intersection of planes $A$ and $B$ can be express as Wsini Therefore, the wedge force can be resolved into components normal to and parallel to the line of intersection of two planes. The location of $\mathrm{W}, \mathrm{NA}, \mathrm{NB}$ and $\mathrm{Ni}$ as well as the measured angle $\beta \mathrm{i}, \delta \mathrm{A}$ and $\delta \mathrm{B}$ must be measures with stereonet or calculated as shown in Figure 5.

5. Determination of force polygons to determine the magnitude of $\mathrm{N}$ (Figure 6).

Force polygons, along with measured angles, used to determine the magnitude of $\mathrm{Nj}$, NA and NB are shown in Figure 6. Then, the factor of safety can be calculated by Equation 7 .

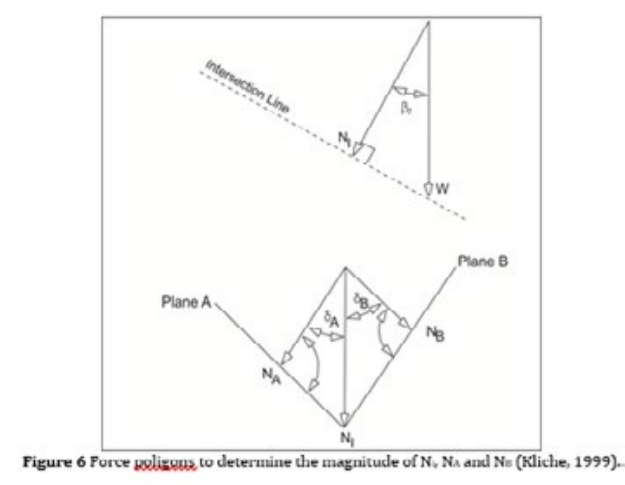

Table 1 The symbols and their definition used in kinetic analysis.

\begin{tabular}{|c|c|}
\hline Remarks & Symbol and definitions \\
\hline Wedge Model & $\begin{array}{l}\text { Plane A - the flatter of the two planes: Plane B - the steeper of the two planes: Line } 1 \text { - the intersection of } \\
\text { plane A with the slope face (SF): Line } 2 \text { - the intersection of plane B with the slope face (SF): Line } 3 \text { - the } \\
\text { intersection of plane A with the upper slope surface (USS): Line } 4 \text { - the intersection of plane B with the } \\
\text { USS: Line } 5 \text { - the intersection of plane A with plane B } \\
\text { If a tension crack exists in the USS, then additional numbering will be } \\
\text { Line } 6 \text { - the intersection USS with SF: Line } 7 \text { - the intersection of the tension crack with plane A : Line } 8 \text { - } \\
\text { the intersection of the tension crack with plane B: Line } 9 \text { - the intersection of the tension crack with USS }\end{array}$ \\
\hline $\begin{array}{l}\text { Planes forming the wedge } \\
\text { and the numbering of } \\
\text { wedge end lines }\end{array}$ & $\begin{array}{l}N_{A}=\text { normal to plane } A_{i} N_{10}=\text { normal to plane } B ; W=\text { weight vector of wedge; } \theta_{1-5}=\text { angle between line } 1 \\
\text { and line } 5 ; \theta_{3.5}=\text { angle between line } 3 \text { and line } 5 ; \theta_{1-3}=\text { angle between line } 1 \text { and line } 3 ; \theta_{4-5}=\text { angle } \\
\text { between line } 4 \text { and line } 5 ; \theta_{2.5}=\text { angle between line } 2 \text { and line } 5 ; \theta_{2-4}=\text { angle between line } 2 \text { and line } 4\end{array}$ \\
\hline Wedge volume & $\begin{array}{l}\text { Line } 5\left(L_{s}\right) \text { - line of intersection between planes } A \text { dan } B ; h_{s}-\text { height of plane } A: h \text { - height of plane } B ; \theta_{w} \\
=\text { internal angle between planes } A \text { and } B \text { and can be equal to } 180 \text {-angle }\left(N_{N} N_{H 1}\right) ; d=\text { wedge height }\end{array}$ \\
\hline Wedge weight & 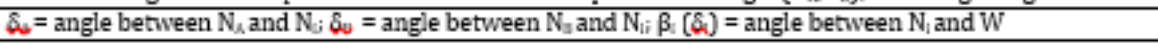 \\
\hline F.O.S. & $\begin{array}{l}A_{n}, A_{E}=\text { area of the two failure planes; } C_{n}, C_{11}=\text { cohesion along planes } A \text { and } B_{i} \Phi_{A}, \Phi_{V}=f r \\
\text { along planes } A \text { and } B_{i} W_{W}=\text { weight of the wedge; } \beta_{i}=\text { plunge of the line of intersection }\end{array}$ \\
\hline
\end{tabular}

Table 2 Parameters for limit equilibrium analysis (kinetic analysis)

\begin{tabular}{|l|l|l|}
\hline Symbol & Parameter & Dimension \\
\hline F. O. S. & Factor of safety against sliding along sheet joint & Calculation \\
\hline H & Vertical height of the line of intersection & Variable $(\mathrm{m})$ \\
\hline$Y_{Y}$ & Unit weight of rock & Calculation $\left(\mathrm{kN} / \mathrm{m}^{\mathrm{j}}\right)$ \\
\hline $\mathrm{C}$ & Cohesive strength along sliding surface & $\begin{array}{l}\text { Variable }\left(\mathrm{kN} / \mathrm{m} / \mathrm{m}^{2}\right) \\
\text { Rock }(\#): \min =3 ; \max =7\end{array}$ \\
\hline$\Phi$ & Friction angle of sliding surface & $\begin{array}{l}\text { Variable }(\text { degree }) \\
\text { Rock }(\#): \min =28 ; \max =32\end{array}$ \\
\hline
\end{tabular}

Note:

\#- Hoek dan Bray (1981). 
Combination of prescriptive measures (Yu et al., 2005) and Markland test (Markland. 1972) have been used to propose slope design in the study area.

\section{RESULT AND DISCUSSION}

The results of the Markland test are shown in Figure 7 and Table 3. The mode of failure is wedge failure. The wedge failures are potential in slope 2 and 3 but only possible in slope 1 and 4 . The wedge failure in slope 1, 2, 3 and 4 have been kinematically formed by the intersection of planes $B$ and $\mathrm{K} 3$, $\mathrm{K} 1$ and $\mathrm{K} 2$, $\mathrm{B}$ and $\mathrm{K} 2$ and $\mathrm{K} 1$ and $\mathrm{K} 3$, respectively.

The stability of selected slopes or factors of safety are shown in Table 4. The limit equilibrium analysis (kinetic analysis) method shows that all of the slopes are generally stable. Most of the slopes (slope 1 to slope 4) are analysis for wedge failure. There are two (2) potential wedge failures in slope 2 but intersection of $\mathrm{K} 1$ and $\mathrm{K} 2$ have been selected as the most potential after evaluated by using NAAF method.

The main factors that control the stability of the slopes are lithological unit and slope height. Most of the slopes are dominated by sandstone beds i.e. $70 \%-95 \%$ (Table 3). The sandstone beds are stronger than shale then the slope become more stable. Most of the slope in the study area are less than $10 \mathrm{~m}$ and considered as lowered slopes. Theoretically, the lower slope is more stable compare to higher slope.

The proposed slope design for the selected slopes are based on Markland test and prescriptive measure and shown in Table 5. Most of the selected slopes are potential and possible to fail then flattening based on optimum slope angle by Markland test is recommended. The range of optimum slope angle varies from 310 to 510 .

The potential and possible wedge failures in slope 1 to slope 4 are proposed for the installation of wire mesh. This wire mesh is useful to trap, reduce and protect the road from falling wedge blocks. Constructions of rock trap ditch at the bottom of the slope are also proposed for slope 1, 2 and 4 which are higher than $5 \mathrm{~m}$. This is because higher slope producing high energy for falling rock block. The block is potentially moving or rolling on the road and endangered users. The potential wedge failure in slopes 2 and 3 are needed for installation of spot rock bolting to protect falling wedge block from slope face.

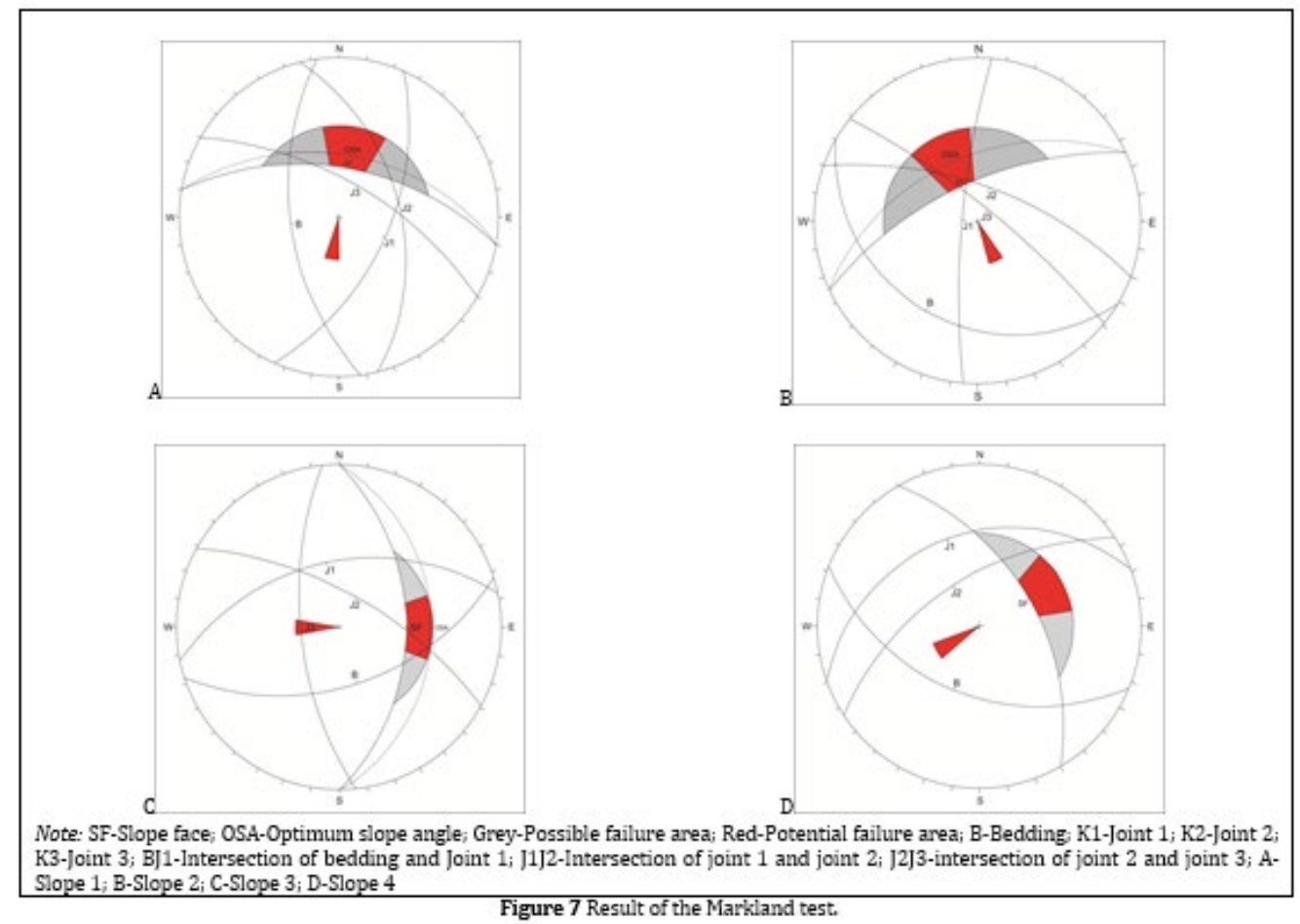

Table 3 Slope geometry, lithological unit and mode of failure for the selected slopes.

\begin{tabular}{|c|c|c|c|c|c|c|}
\hline Locality & $\begin{array}{l}\text { Slope face \& } \\
\text { Upper slope } \\
\text { face } \\
\text { (strike/dip) }\end{array}$ & Lithological unit & Height $(\mathrm{m})$ & $\begin{array}{l}\text { Mode of failure } \\
\text { (most critical) }\end{array}$ & $\begin{array}{l}\text { Discontinuity } \\
\text { planes }\end{array}$ & $\begin{array}{l}\text { Failure planes } \\
\text { (strike/dip) }\end{array}$ \\
\hline S1 & $\begin{array}{l}280 / 55 \& \\
280 / 12\end{array}$ & $\begin{array}{l}\text { Ss and Sh interbeds; } \\
\text { dominant \$s (80\%) }\end{array}$ & 7.75 & Wedge & BK3 & $\begin{array}{l}\mathrm{B}-172 / 56 \\
\mathrm{~K} 3-300 / 64\end{array}$ \\
\hline 52 & $\begin{array}{l}245 / 63 \& \\
245 / 13\end{array}$ & $\begin{array}{l}\text { Ss and Sh interbeds; } \\
\text { dominant \$s }(90 \%)\end{array}$ & 5.85 & Wedge & K1K2 & $\begin{array}{l}\mathrm{K} 1-290 / 65 \\
\mathrm{~K} 2-185 / 79\end{array}$ \\
\hline 53 & $\begin{array}{l}360 / 45 \& \\
360 / 14\end{array}$ & $\begin{array}{l}\text { Ss and Sh interbeds; } \\
\text { dominant \$s ( } 95 \%)\end{array}$ & 2.94 & Wedge & BK2 & $\begin{array}{l}\mathrm{B}-72 / 50 \\
\mathrm{~K} 2-299 / 66\end{array}$ \\
\hline 54 & $\begin{array}{l}330 / 51 \& \\
330 / 12\end{array}$ & $\begin{array}{l}\text { Ss and Sh interbeds; } \\
\text { dominant \$s (70\%) }\end{array}$ & 4.68 & Wedge & K1K3 & $\begin{array}{l}\mathrm{K} 1-353 / 78 \\
\mathrm{~K} 3-250 / 30\end{array}$ \\
\hline
\end{tabular}

\footnotetext{
Note: Ss-Sandstone; Sh-Shale
} 
Table 4 Wedge characteristics and the value of factor of safety.

\begin{tabular}{|c|c|c|c|c|c|}
\hline Locality & $\begin{array}{c}\text { Width of plane A } \\
\left(\mathrm{m}^{2}\right)\end{array}$ & $\begin{array}{c}\text { Width of plane B } \\
\left(\mathrm{m}^{2}\right)\end{array}$ & $\begin{array}{c}\text { Wedge volume } \\
\left(\mathrm{m}^{2}\right)\end{array}$ & $\begin{array}{c}\text { Wedge weight } \\
(\mathrm{Kg})\end{array}$ & Factor of safety \\
\hline S1 & 17.96 & 7.36 & 6.35 & 15049.5 & 1.93 \\
\hline S2 & 1.43 & 0.98 & 0.137 & 323.93 & 3.01 \\
\hline S3 & 4.07 & 4.34 & 1.66 & 3934.2 & 2.50 \\
\hline S4 & 3.07 & 2.36 & 0.48 & 1137.6 & 4.43 \\
\hline
\end{tabular}

Table 5 Propose slope design.

\begin{tabular}{|c|l|c|c|c|}
\hline \multirow{2}{*}{ Locality } & $\begin{array}{l}\text { Flattening } \\
\text { (Optimum slope } \\
\text { angle) }\end{array}$ & Wire mesh & Rock trap ditch & Rock bolting (spot) \\
\hline S1 & 47 & $\sqrt{ }$ & \\
\hline S2 & 47 & $\sqrt{ }$ & $\sqrt{ }$ \\
\hline S3 & 31 & $\sqrt{ }$ & $\sqrt{ }$ \\
\hline S4 & 45 & $\sqrt{ }$ & $\sqrt{ }$ \\
\hline
\end{tabular}

\section{CONCLUSIONS}

Conclusions of this study are:

1. The modes of failures are wedge and planar failure.

2. The factors of safety ranges from 1.93 to 4.43 by calculation and generally stable..

3. The proposed slope design are flattening based on 310-45o optimum slope angles, installation of the wire mesh, rock trap ditch and spot rock bolting.

\section{REFERENCES}

Ismail Abd Rahim, Sanudin Hj. Tahir, Baba Musta and Shariff A. K. Omang. 2010. Slope stability evaluation of selected rock cut slope of the Crocker Formation in Kota Kinabalu, Sabah. Proceeding of the 3rd Southeast Asian Natural Resources and Environmental Management (SANREM 2010), 3-5 August 2010, Promenade Hotel, Kota Kinabalu, Sabah.

Ismail Abd Rahim, Sanudin Hj. Tahir, Baba Musta, \& Shariff A. K. Omang. 2012. Adjustment factor for Slope Mass Rating (SMR) system: Revisited. Prosiding Persidangan Geosains Kebangsaan 2012 (NGC2012), 22-23 Jun 2012, Hotel Pullman, Kuching, Sarawak.

ISRM, 1981. Rock Characterization, Testing and Monitoring. In: Brown, E.T. (Ed.). International Society for Rock Mechanics (ISRM) Suggested Methods. Pergamon, Oxford. $211 \mathrm{pp}$.

ISRM, 2007. The Complete ISRM Suggested Mothods for Rock Characterization, Testing and Monitoring: 1974-2006. In: Ulusay, R. \& Hudson. J. A. (Ed.). Commission on Testing Methods International Society for Rock Mechanics (ISRM). Elsevier. 627 pp.

Kliche, C.A., 1999. Rock slope stability. Society for Mining, Metallurgy and Exploration, Inc.

Maerz, N. H. 2000. Highway rock cut stability assessment in rock masses not conducive to stability calculations. Proceeding of the 51st Annual Highway Symposium, Seattle, Washington, 29 August-1 September 2000: 249-259. Markland, J. T. (1972). A Useful technique for estimating the stability of rock slopes when the rigid wedge slide type of failure is expected. Imperial College Rock Mechanics Research reprint, no. 19.

Sanudin Tahir \& Baba Musta. 2007. Pengenalan Kepada Stratigrafi. Universiti Malaysia Sabah, Kota Kinabalu, Sabah.

Yu, Y. F., Siu, C. K. \& Pun, W. K. 2005. Guidelines on the use of prescriptive measures for rock cut slopes. GEO Report No. 161, Hong Kong Geotechnical Engineering Office, 31p. 